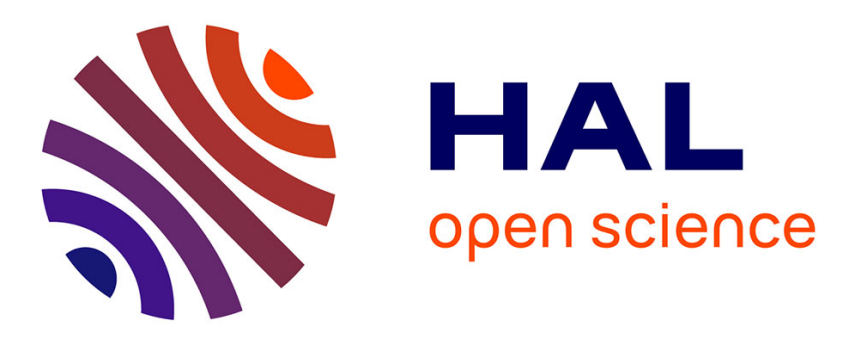

\title{
Methodological pitfalls in serum IgG2 level measurements by immunoenzymatic assays with monoclonal antibodies.
}

Pierre Aucouturier, Corinne Lacombe, Jean-Louis Preud'Homme

\section{- To cite this version:}

Pierre Aucouturier, Corinne Lacombe, Jean-Louis Preud'Homme. Methodological pitfalls in serum IgG2 level measurements by immunoenzymatic assays with monoclonal antibodies.. Journal of Clinical Laboratory Analysis, 1992, 6 (1), pp.12-6. inserm-01900606

\section{HAL Id: inserm-01900606 https://www.hal.inserm.fr/inserm-01900606}

Submitted on 22 Oct 2018

HAL is a multi-disciplinary open access archive for the deposit and dissemination of scientific research documents, whether they are published or not. The documents may come from teaching and research institutions in France or abroad, or from public or private research centers.
L'archive ouverte pluridisciplinaire HAL, est destinée au dépôt et à la diffusion de documents scientifiques de niveau recherche, publiés ou non, émanant des établissements d'enseignement et de recherche français ou étrangers, des laboratoires publics ou privés. 


\title{
Methodological Pitfalls in Serum IgG2 Level Measurements by Immunoenzymatic Assays With Monoclonal Antibodies
}

\author{
Pierre Aucouturier, Corinne Lacombe, and Jean-Louis Preud'homme \\ Laboratory of Immunology and Immunopathology, CNRS URA 1172, CHUR, BP 577, Poitiers Cedex, France
}

\begin{abstract}
Four anti-IgG2 monoclonal antibodies (Mabs) were evaluated for their reactivity with purified myeloma lgG2 of different light chain types and $\mathrm{Gm}$ allotypes in three distinct immunoenzymatic assays (ELISA). The reactivity of three Mabs with solid-phase antigens was similar whereas an anti-Fab antibody (clone HP 6114) predominantly bound lgG2к. In competitive and immunometric (sandwich type) assays, the binding of the two anti-lgG2 Mabs (HP 6014 and HP 6114) reacting with epitopes located on the Fab fragment was strongly influenced by the light chain type of

ing differences in the variable regions): the Mab HP 6114 reacted virtually only with $\lg \mathrm{G} 2 \kappa$ whereas the Mab HP 6014 displayed a much stronger affinity for $\lg G 2 \lambda$ than for IgG2к; for both anti-Fab Mabs, important differences were found in their binding to individual IgG2 proteins. In addition, the Mab HP 6014 seemed to show a slightly better affinity for $\lg \mathrm{G} 2$ bearing the $\mathrm{Gm}(23)$ allotype. These results urge much caution in IgG2 level measurement, especially with commercial kits, most of which use the Mab 6014 as the single anti-lgG2 reagent.
\end{abstract} IgG2 and by other factors (probably includ-

Key words: immunoglobulin subclasses, immunoassays, light chain type, allotype, ELISA

\section{INTRODUCTION}

Human IgG are made up of four subclasses differing by relatively few amino acid changes in the heavy chain constant region (mean homology 95\%) (see ref. 1 and 2 for refiews). Not surprisingly, measurement of body fluid IgG subclass levels has long been hampered by the difficulty to prepare specific polyclonal antisera. In the last decade, the availability of anti-subclass monoclonal antibodies (Mabs) allowed numerous studies of these isotypes in normal and diseased individuals (reviewed in ref. 2 and 3). An important finding provided by these studies is the high frequency of IgG2 deficiency which occurs as an isolated deficiency or in association with various primary and secondary immunodeficiency states, especially those featuring a $T$ helper cell function impairment (3-6). Of the four subclasses, IgG2 is clinically the most important to measure. Anti- $\gamma 2$ producing hybridomas are more difficult to obtain than those directed against the other subclasses. In a study (7), only $0.3 \%$ of anti-Ig clones were IgG2-specific, as compared with $1.8 \%, 2.5 \%$, and $12 \%$ for IgG $1, \mathrm{IgG} 3$ and IgG4, respectively. Consequently, there is a scarcity of anti-IgG2 Mabs and most commercially available kits employ the very same reagent.

Ig concentration measurements are skewed by a number of individual factors of heterogeneity, such as isotypic (light chain type ratio), allotypic, and idiotypic variability. Mab technology offers the potential possibility of choosing epitopes or recognition systems which are not (or as little as possible) influenced by these parameters. However, because of technical simplicity, hybridoma screening is generally performed using solid-phase antigens and anti-human IgG subclass Mabs have been selected by hemagglutination techniques (8), indirect immunoenzymatic (ELISA) (7), or immunofluorimetric (9) assays. Yet the reactivity of these Mabs is sometimes much dependent on the physicochemical status of the measured IgG, as evidenced by the "assay restriction" found for most of them in a collaborative study (10). Moreover, it is worth noting that almost all published immunoenzymatic methods for IgG subclass-level measurement are based upon a reaction with fluid-phase antigens, either in immunometric (sandwich type) $(11,12)$ or competitive $(13,14)$ assays, although the Mabs had been primarily evaluated in solid-phase systems. This observation, the recent spread of IgG subclass measurement in clinical practice, and the major clinical relevance of IgG2 led us to evaluate commonly employed anti- $\gamma 2$ Mabs in different assays. Results show that the most widely used antibody, although it is IgG2 specific and shows a high affinity, does not react equally with individual monoclonal IgG2. Differences relate to several factors, the most important one being IgG2 light chain type.

\section{MATERIALS AND METHODS}

\section{Antibodies}

Aliquots of ascitic fluids containing Mabs from clones GOM 1 ( = HP 6008), GOM 2 ( = HP 6009) (anti-IgG2 Fc,

Received July 10, 1991; accepted August 22, 1991.

Address reprint requests to P. Aucouturier, CNRS URA 1172, CHUR, BP 577, F-86021 Poitiers Cedex, France. 
Oxoid, Bedford, UK), HP 6014, and HP 6114 (anti-IgG2 Fab, kindly provided by Dr. C.B. Reimer, Atlanta, GA) were kept frozen and extemporaneously diluted in $0.01 \mathrm{M}$ phosphatebuffered saline $\mathrm{pH} 7.4$ (PBS) containing $0.2 \%$ bovine serum albumine (BSA). Dilutions were adapted in order to obtain comparable optical densities (OD) with every Mab on plates coated with $2 \mu \mathrm{g} / \mathrm{ml} \mathrm{IgG2,} \mathrm{except} \mathrm{for} \mathrm{HP} \mathrm{6114,} \mathrm{which} \mathrm{yielded}$ a lower signal.

\section{Antigens}

Eight monoclonal IgG2 (Table 1) of each light chain type

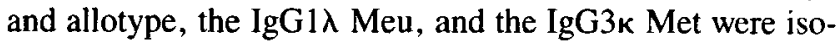
lated from myeloma sera containing low levels of polyclonal Ig by DEAE-trisacryl (IBF, Villeneuve la Garenne, France) chromatography in $10 \mathrm{mM}$ TRIS- $\mathrm{HCl}$ buffer $\mathrm{pH} 7.5$ and eluted with a linear 0 to $0.3 \mathrm{M} \mathrm{NaCl}$ gradient. Monomeric IgG fractions were then separated by gel filtration on Ultrogel ACA34 (IBF) in $1 \mathrm{M} \mathrm{NaCl}, 1 \%$ butanol, $0.1 \mathrm{M}$ TRIS-HCl buffer $\mathrm{pH}$ 8. These fractions were concentrated by negative pressure dialysis at $4^{\circ} \mathrm{C}$, controlled by standard immunoelectrophoresis, and calibrated on the basis of their absorbance at $280 \mathrm{~nm}$. They were used immediately or were stored at $-80^{\circ} \mathrm{C}$ in $50 \mu \mathrm{l}$ aliquots with $5 \% \mathrm{BSA}, 1 \%$ butanol, $5 \mathrm{mM}$ $\epsilon$-aminocaproic acid, and $1 \mathrm{mM}$ phenylmethylsulfonylfluoride to prevent aggregation and proteolysis.

\section{Indirect ELISA}

Flat-bottomed polystyrene microtitration plates (Nunc, Roskilde, Danemark) were coated by overnight incubation at $4^{\circ} \mathrm{C}$ with $200 \mu \mathrm{l}$ per well of solutions of the IgG2 Com, Jal, Rui, Hau, Blo, and Poi and of the IgG1 Meu and of the IgG3 Met each at $2 \mu \mathrm{g} / \mathrm{ml}$ in $0.1 \mathrm{M}$ sodium carbonate buffer $\mathrm{pH}$ 9.6. To allow comparisons, individual ELISA plates were coated with all eight monoclonal Ig. After a saturation step with $0.2 \%$ BSA, $200 \mu \mathrm{l}$ of Mabs diluted in $0.2 \%$ PBS-BSA was added in triplicate and left to incubate for 18 hours at $4^{\circ} \mathrm{C}$. Plates were washed four times with PBS containing $0.05 \%$ Tween 20 (PBS-T) and revealed by incubating with a peroxidase-conjugated rabbit anti-mouse IgG antibody (HRPanti-MIgG, prepared in our laboratory) in PBS-T for 1 hour at room temperature. Plates were washed six times with PBS-T and the enzymatic reaction was performed with

TABLE 1. Purified Human Monoclonal IgG2 Used in the Study

\begin{tabular}{lcc} 
Patient & Light chain type & Gm(23) allotype \\
\hline Com. & $\kappa$ & - \\
Jal. & $\kappa$ & - \\
Den. & $\kappa$ & + \\
Rui. & $\kappa$ & + \\
Hau. & $\lambda$ & - \\
Ouv. & $\lambda$ & - \\
Blo. & $\lambda$ & + \\
Poi. & $\lambda$ & + \\
\hline
\end{tabular}

$0.012 \% \mathrm{H}_{2} \mathrm{O}_{2} \quad 0.4 \mathrm{mg} / \mathrm{ml}$ o-phenylenediamine in $50 \mathrm{mM}$ sodium citrate buffer $\mathrm{pH} 5$.

\section{Competitive ELISA}

The principle of inhibition assays with immobilized antigens has been described in detail previously $(13,14)$. Briefly, polystyrene plates were coated with mixture of $\operatorname{IgG} 2 \kappa$ and $\operatorname{IgG} 2 \lambda(1 \mu \mathrm{g} / \mathrm{ml}$ each $)$ as above and saturated with $0.2 \%$ BSA. Each Mab was then incubated for 24 hours at $4^{\circ} \mathrm{C}$ in the presence of various concentrations of different myeloma IgG2, and the bound fraction was revealed by HRP-anti-MIgG as above. Each point was tested in quadruplicate.

\section{Immunometric ELISA}

Plates were coated in the same conditions as above with rabbit polyclonal anti-mouse IgG antibodies (IgG fraction adsorbed on human IgG, prepared in our laboratory) at 10 $\mu \mathrm{g} / \mathrm{ml}$. After washings with PBS, Mabs at appropriate dilutions in PBS-BSA $0.2 \%$ were added and left to incubate for 1 hour at $37^{\circ} \mathrm{C}$. Myeloma protein samples were incubated for 24 hours at $4^{\circ} \mathrm{C}$ in triplicate, the plates were washed with PBS-T, and the bound fraction was revealed by incubating 1 hour at $37^{\circ} \mathrm{C}$ with sheep peroxidase-conjugated anti-human IgG antibody (Binding Site Ltd, Birmingham, UK) diluted 1:7,000 in PBS with 2\% normal rabbit serum.

\section{RESULTS}

Reactivities of the Mabs with solid-phase antigens were first evaluated by indirect ELISA. In spite of a minor variability which might relate to differences in epitope presentation and

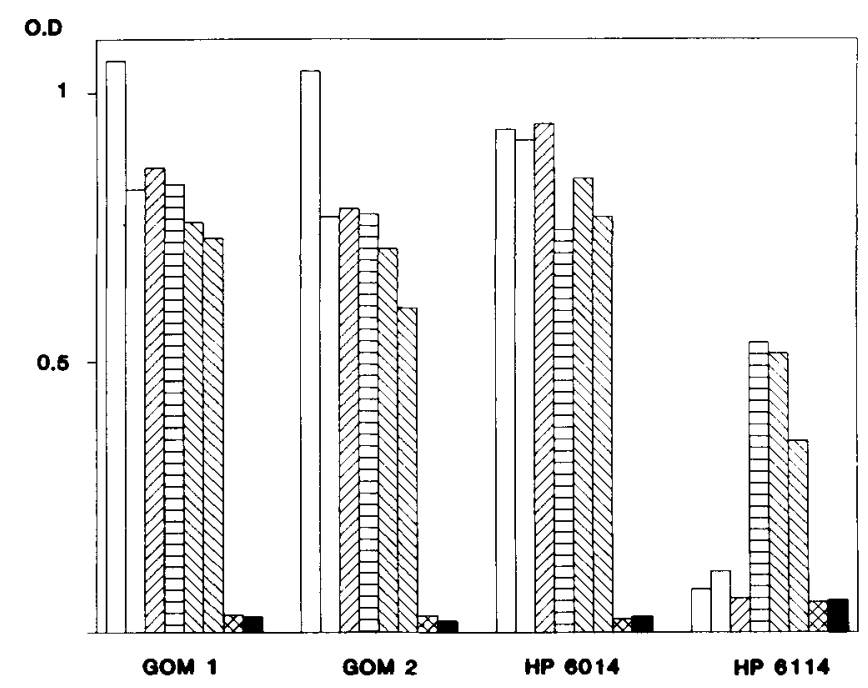

Fig. 1. Binding of anti-IgG2 Mabs to six purified monoclonal IgG2 adsorbed on polystyrene (indirect ELISA) $(\mathrm{O}: \operatorname{lgG} 2 \lambda, \mathrm{Gm} 23$-positive $\oslash$ :

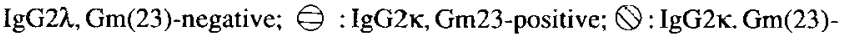
negative). The purified human myeloma $\operatorname{IgG} 1 \lambda(\otimes)$ and $\operatorname{IgG} 3 \kappa(\square)$ were tested as controls. 
GOM 1

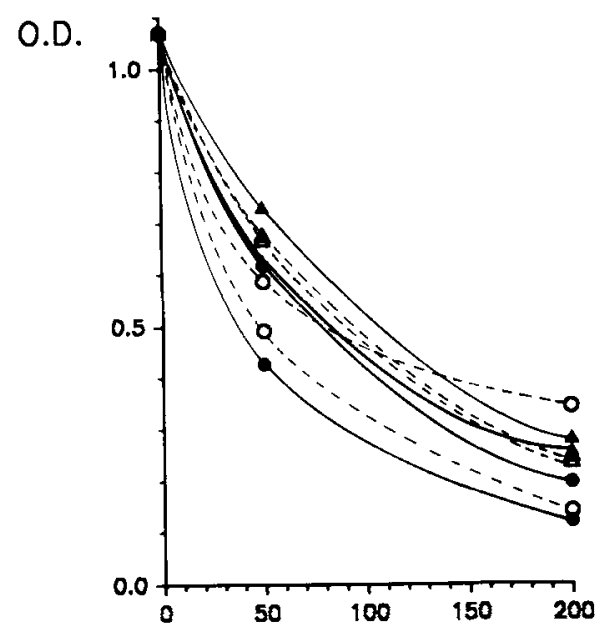

Fig. 2. Inhibition of the binding of anti-IgG2 Fc Mabs to an IgG2 $\mathrm{K}+$ $\operatorname{IgG} 2 \lambda$ coat by eight purified monoclonal IgG2 of each light chain type and $\mathrm{Gm}$ allotype in solution. $\kappa$ molecules are represented by open symbols and dashed lines, $\lambda$ molecules by closed symbols and continuous lines, $\mathrm{Gm}(23)$ -
GOM 2

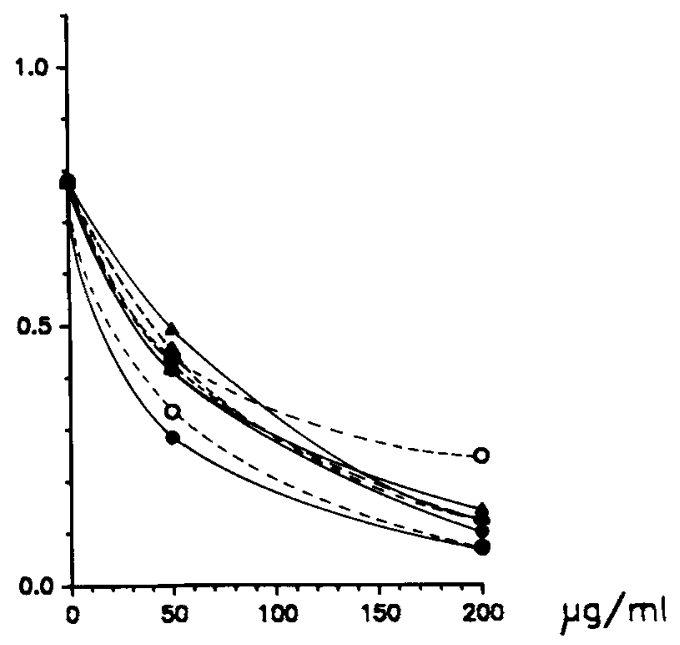

positive molecules by circles, and $\mathrm{Gm}(23)$-negative molecules by triangles. For instance, - - $\triangle$ - - stands for an $\operatorname{IgG} 2 \kappa \mathrm{Gm}(23)$-negative and $\longrightarrow-$ is an $\operatorname{IgG} 2 \lambda \mathrm{Gm}(23)$-positive.
HP 6014

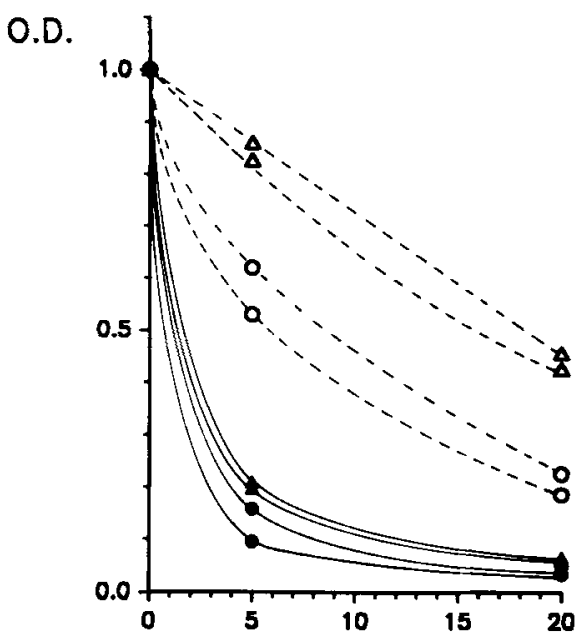

HP 6114

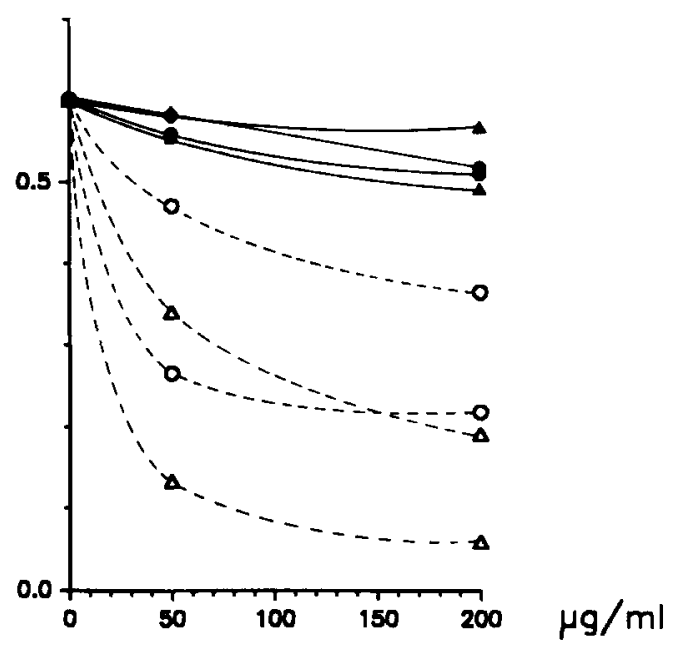

Fig. 3. Inhibition of binding of anti-IgG2 Fab Mabs by eight purified monoclonal IgG2 in soluble form. See legend to Figure 2 for symbols.

coating efficiency, no effect of light chain type or Gm allotype was found for Mabs GOM 1 and GOM 2, the same pattern of reactivity with the $6 \mathrm{IgG} 2$ being observed with these two anti-Fc Mabs. The antibody HP 6014 yielded a slightly higher signal with $\lambda$-type molecules (mean 19\% more than with $\kappa$-type IgG2 after subtraction of the non-specific background), and HP 6114 was virtually IgG2 $\kappa$-specific (Fig. 1).

Much greater differences in IgG2 binding were found in those assays which measure fluid-phase antigen-antibody reactions. In competitive ELISA, virtually no variability was observed with the anti-Fc Mabs (Fig. 2), whereas strong bias was obvious with the anti-Fab Mabs (Fig. 3). Binding of the
Mab HP 6014 was much more inhibited by $\operatorname{IgG} 2 \lambda$ than by IgG $2 \kappa$ proteins and, inside each light chain type, by $\mathrm{Gm}(23)$ positive proteins (Table 2). The Mab HP 6114 was almost IgG $2 \kappa$-specific. On the whole, although the Mab HP 6014 displayed the highest apparent affinity (as shown by the mean antigen concentration required for $50 \%$ inhibition), the Mabs GOM 1 and GOM 2, which showed a similar reactivity with IgG2 of both light chain types, were potentially better reagents for IgG2 measurement (Table 3).

A similar pattern of reactivity with myeloma IgG was found for the anti-Fab Mabs in immunometric ELISA (Fig. 4). Again, OD recorded with the Mab HP 6014 were 
TABLE 2. Monoclonal IgG2 Concentrations $(\mu \mathrm{g} / \mathrm{ml})$ Yielding $50 \%$ Inhibition of Binding of the Mab HP 6014 in an Competitive ELISA, as a Function of Light Chain Type and Gm Allotype

\begin{tabular}{|c|c|c|c|}
\hline & \multicolumn{2}{|c|}{ Light chain type } & \multirow[b]{2}{*}{ Mean \pm s.d. } \\
\hline & Kappa & Lambda & \\
\hline \multicolumn{4}{|l|}{$\operatorname{Gm}(23)$} \\
\hline Positive & $\begin{array}{ll}\text { Den. } & 5.5 \\
\text { Rui. } & 8.0\end{array}$ & $\begin{array}{l}\text { Blo. } 0.9 \\
\text { Poi. } 1.25\end{array}$ & $3.9 \pm 3.0$ \\
\hline Negative & $\begin{array}{c}\text { Com. 18.1 } \\
\text { Jal. } 16.3\end{array}$ & $\begin{array}{l}\text { Ouv. } 1.7 \\
\text { Hau. } 1.5\end{array}$ & $9.4 \pm 7.8$ \\
\hline Mean \pm s.d. & $12 \pm 5.3$ & $1.3 \pm 0.3$ & \\
\hline
\end{tabular}

TABLE 3. IgG2 Concentrations ( $\mu \mathrm{g} / \mathrm{ml}$, Mean \pm s.d.) Yielding $50 \%$ Inhibition of Mab Binding in a Competitive ELISA

\begin{tabular}{lcc}
\hline & \multicolumn{2}{c}{ Light chain type of IgG2 } \\
\cline { 2 - 3 } Antibody & Kappa $(n=4)$ & Lambda $(n=4)$ \\
\hline HP 6014 & $12 \pm 5.3$ & $1.3 \pm 0.3$ \\
HP 6114 & $97 \pm 136$ & $>>200$ \\
HP 6008 (GOM 1) & $59 \pm 14$ & $58 \pm 23$ \\
HP 6009 (GOM 2) & $56 \pm 12$ & $56 \pm 25$ \\
\hline
\end{tabular}

approximately nine times higher with $\lambda$ than with $\kappa$ molecules, and about double with those bearing the $\operatorname{Gm}(23)$ allotype than with those negative for this marker (Table 4). The Mabs GOM 1 and GOM 2 did not yield significant results using this assay because of important non-specific background signals.

\section{DISCUSSION}

The present study shows that the reactivity of Mabs directed to Fab epitopes of IgG2 is strongly biased by the light chain type, Gm allotype, and probably other factors linked to the
V regions. Such effects on the reactivity of the Mab HP 6014 were much less apparent when the $\operatorname{IgG} 2$ antigens were adsorbed on a solid surface, whereas the Mab HP 6114 was almost specific for IgG2 $\kappa$ in all types of assays. The light chain bias (but not the Gm (23) influence) of the Mab 6014 was already reported in a particle concentration fluorescence immunoassay (15). In that study, the detection efficiency was five times higher with $\lambda$ than with $\kappa$-type $\operatorname{IgG} 2$. In the present study, the mean IgG concentration needed to yield the same signal was nine times higher for $\operatorname{IgG} 2 \kappa$ than for $\operatorname{IgG} 2 \lambda$ by competitive and immunometric ELISA. No correction of this bias could be obtained by antibody excess since antigen dilution curves showed similar differences whatever the antigen concentration. A more marginal (about two-fold) difference in the reactivity of the Mab HP 6014 was apparent according to the allotype $\mathrm{Gm}(23)$. This Mab displays a high affinity for IgG2 and, in an international IUIS/WHO collaboration study, it was considered the only specific anti-IgG2 Mab having a satisfactory avidity in ELISA (10). Consequently, it is the anti-IgG2 reagent in most commercial kits for IgG subclass measurement. We have tested the two most widely used ELISA kits (The Binding Site Ltd., Birmingham, UK, and Janssen Biochimica, Beerse, Belgium) and the results confirmed the present study (data not shown).

The only amino acids in the $\mathrm{CH} 1$ domain specific for IgG2 are Asn 192 and Phe 193 (1). Their location in the loop between the $\beta$-sheets $4-4$ and 3-2 (16) suggests that the corresponding epitope might be influenced by environmental factors. This epitope could be more or less accessible to the Mab HP 6014 (if it reacted with this determinant, which is a mere hypothesis) when IgG2 of different light chain type and Gm allotype are in solution, whereas it might be largely unmasked
HP 6014

O.D.

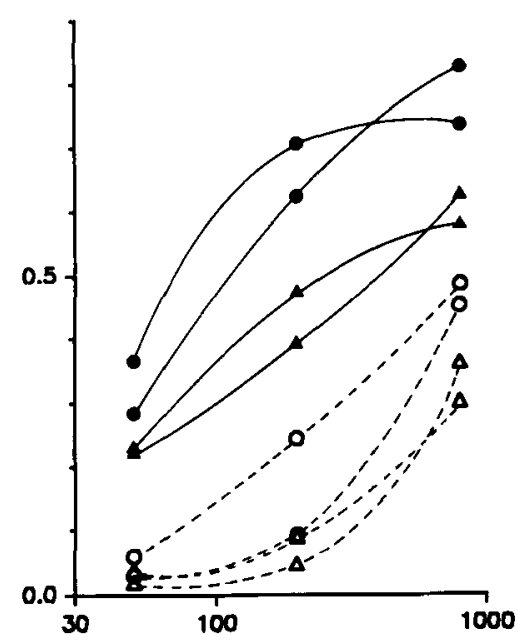

HP 6114

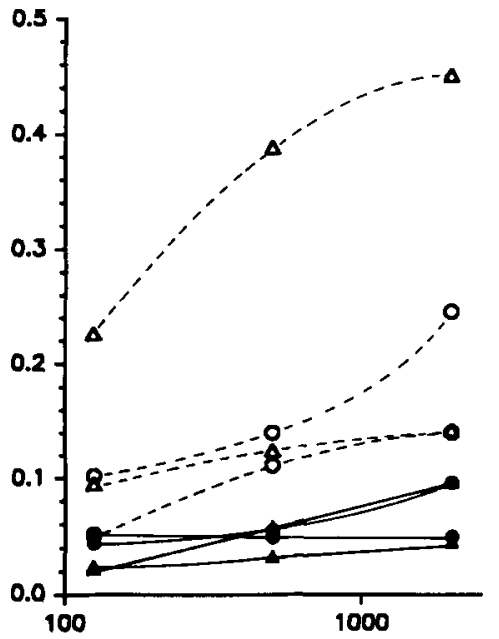

$\mathrm{ng} / \mathrm{ml}$

Fig. 4. Binding of eight purified monoclonal IgG2 to anti-IgG2 Fab Mabs by immunometric ELISA. Same symbols as in Figures 2 and 3. 
TABLE 4. Monoclonal IgG2 Concentrations $(\mu \mathrm{g} / \mathrm{ml})$ Yielding an O.D. of 0.3 With the Mab HP 6014 in an Immunometric ELISA, as a Function of Light Chain Type and Gm Allotype

\begin{tabular}{lccc} 
& \multicolumn{2}{c}{ Light chain type } & \\
\cline { 2 - 3 } & Kappa & Lambda & Mean \pm s.d. \\
\hline GM(23) & & & \\
Positive & Den. 287 & Blo. 44 & $230 \pm 201$ \\
& Rui. 535 & Poi. 53 & \\
Negative & Com. 740 & Ouv. 98 & $427 \pm 348$ \\
& Jal. 800 & Hau. 70 & \\
Mean \pm s.d. & $591 \pm 231$ & $66 \pm 24$ & \\
\hline
\end{tabular}

after adsorption on a solid phase. The epitope recognized by HP 6014 might also be a conformational determinant made up of structures carried by both the heavy and the light chains. Such a hypothesis probably applies to the Mab 6114 which binds virtually only IgG $2 \kappa$ both in liquid- and solid-phase forms. The influence of the $\mathrm{Gm}(23)$ allotype on the reactivity of $\mathrm{IgG} 2$ with the anti-Fab Mabs, which is suggested by the present study and requires further studies to be confirmed, is more difficult to explain since the structural differences between $\mathrm{IgG} 2$ alleles are not yet fully characterized. Substitution between a Ser and an Ala at position 177 has been described (17), but there is no clear-cut evidence that it relates to allotypy.

As shown by measuring IgG2 in some sera by using separately Mabs HP 6014 and GOM 2 in competitive ELISA, the former often yields false levels. A serum imbalance of the $\kappa / \lambda$ ratio may lead to over- or underestimate of $\mathrm{IgG} 2$ levels, depending on the Mab used. IgG2 deficiency is frequent in a variety of conditions, including those featuring a $T$ cell defect or a defective T-B cell cooperation (2-6). It is worth recalling that there is some evidence for an increased expression of $\lambda$ light chains in certain immunodeficiency states, noticeably when there is a $\mathrm{T}$ cell functional defect $(18,19)$. On the other hand, specific antibody responses are sometimes largely light chain restricted, as with the response to the capsular polysaccharide of Haemophilus influenzae, which shows a clear $\kappa$ predominance (20). Such a predominant monotypy may introduce a potential error in the evaluation of the subclass distribution of IgG antibodies to the corresponding antigens when using anti-IgG2 Fab Mabs. A solution of this problem is the use of a mixture of two Mabs in suitable proportion (21).

In contrast to the anti-Fab Mabs, the anti-IgG2 Fc Mabs GOM 1 and GOM 2 reacted virtually equally with all monoclonal IgG2 tested in the present study. These Mabs display an affinity for IgG2 lower than that of the Mab HP 6014 and this makes them hardly usable in sensitive sandwich assays. However, they have performed in assays such as the competitive ELISA developed in our laboratory and we recommend their use under such technical conditions.

\section{ACKNOWLEDGMENTS}

We thank Dr. G. de Lange for allotype determinations and the late Dr. C.B. Reimer (Atlanta) for the kind gift of the Mabs HP 6014 and HP 6114.

\section{REFERENCES}

1. Burton DR, Gregory L, Jefferis R: Aspects of the molecular structure of IgG subclasses. Monogr Allergy 19:7-35, 1986.

2. Normansell DE: Human immunoglobulin subclasses. Diagn Clin Immunol 5:115-126, 1987.

3. Preud'homme JL, Hanson LA: IgG subclass deficiency. Immunodeficiency Rev 2:129-149, 1990.

4. Oxelius VA: Immunoglobulin $\mathrm{G}$ ( $\mathrm{IgG}$ ) subclasses and human disease. Am J Med 76:7-18, 1984.

5. Aucouturier P, Lacombe C, Bremard C, Lebranchu Y, Seligmann M, Griscelli C, Preud'homme JL: Serum IgG subclass levels in patients with primary immunodeficiency syndromes or abnormal susceptibility to infections. Clin Immunol Immunopathol 51:22-37, 1989.

6. Regueiro JR, Perez-Aciego P, Aparicio P, Martinez-A C, Morales P, Arnaiz-Villena A: Low IgG2 and polysaccharide response in a $T$ cell receptor expression defect. Eur J Immunol 20:2411-2416, 1990.

7. Sarnesto A: Monoclonal antibodies reacting with isotypic and/or allotypic determinants of human IgG. Med Biol 61:126-132, 1983.

8. Lowe J, Bird P, Hardie D, Jefferis R, Ling N: Monoclonal antibodies (McAbs) to determinants on hurnan gamma chains: properties of antibodies showing subclass restriction or subclass specificity. Immunology 47:329-336, 1982

9. Reimer CB, Phillips DJ, Aloisio CH, Moore DD, Galland GG, Wells TW, Black CM, McDougal JS: Evaluation of thirty-one mouse monoclonal antibodies to human IgG epitopes. Hybridoma 3:263-276, 1984.

10. Jefferis R, Reimer CB, Skvaril F, de Lange G, Ling NR, Lowe J, Walker MR, Phillips DJ, Aloisio CH, Wells TW, Vaerman JP, Magnusson CG, Kubagawa H, Cooper M, Vartdal F, Vandvik B, Haaijman JJ, Makela O, Sarnesto A, Lando Z, Gergely J, Rajnavölgyi E, Laszlo G, Radl J, Molinaro GA: Evaluation of monoclonal antibodies having specificity for human IgG subclasses: resuits or an IUIS/WHO collaborative study. Immunol Lett 10:223-252, 1985.

11. Ferrante A, Rowan-Kelly B, Beard LJ, Maxwell GM: An enzyme-linked immunosorbent assay for the quantitation of human IgG subclasses using monoclonal antibodies. J Immunol Methods 93:207-212, 1986.

12. Papadea C, Check IJ, Reimer CB: Monoclonal antibody-based solidphase immunoenzymatic assays for quantifying human immunoglobulin $\mathrm{G}$ and its subclasses in serum. Clin Chem 31:1940-1945, 1985.

13. Aucouturier P, Danon F, Daveau M, Guillou B, Sabbah A, Besson J, Preud homme JL: Measurement of serum IgG4 levels by a competitive immunoenzymatic assay with monoclonal antibodies. $J$ Immunol Methods 74:151-162, 1984.

14. Aucouturier P, Mounir S, Preud'homme JL: Distribution of IgG subclass levels in normal adult sera as determined by a competitive enzyme immunoassay using monoclonal antibodies. Diagn Immunol 3:191-196, 1985.

15. Madassery JV, Kwon OH, Lee SY, Nahm MH: IgG2 subclass deficiency: IgG subclass assays and IgG2 concentrations among 8015 blood donors. Clin Chem 34:1407-1413, 1988.

16. Putman FW: Immunoglobulins: structure, function and genes. In The Plasma Proteins: Structure, Function, and Genetic Control. FW Putman, ed. Academic Press, Orlando, 1987, pp 49-140

17. de Lange GG: Monoclonal Antibodies Against Human Immunoglobulin Allotype. PhD Thesis, University of London, 1988.

18. Cooper MD, Lawton AR, Preud'homme JL, Seligmann M: Primary antibody deficiency. Springer Semin Immunopathol 1:265-281, 1978.

19. Van den Akker TW, Benner R, Radl J: Transient monoclonal gammapathies with lambda light chains. Transplantation 44:725-726, 1987.

20. Insel RA, Kittelberger A, Anderson P: Isoelectric focusing of human antibody to the Haemophilus influenzae type $b$ capsular polysaccharide: restricted and identical spectrotypes in adults. $J$ Immunol 135 : 2810-2816, 1985

21. Barra A, Schulz D, Aucouturier P, Preud'homme JL: Measurement of anti-Haemophilus influenzae type B capsular polysaccharide antibodies by ELISA. J Immunol Methods 115:111-117, 1988. 